\title{
THE RESEARCH OF PARALLEL TO THE GRAIN COMPRESSION PERFORMANCE TEST OF LAMINATED GLUED BAMBOO-WOOD COMPOSITES
}

\author{
Nan Guo, Huihui Chen, Pingyang Zhang, Hongliang Zuo
}

Original scientific paper

Research of bamboo-wood composites compression performance provides a basis for material selections for prestressed glued bamboo-wood beams and other components whose compression is mainly shared by glued bamboo-wooden composites. Four kinds of wood and two kinds of bamboo were selected to comprise 22 groups (6 specimens each group) divided into 4 batches to study the influence factors on bamboo/wooden material type; factors such as composition pattern, layer plate thickness, and lamina lay-ups type. Compressive strength, elasticity modulus, ductility, and failure mechanisms were all compared and analysed. Results showed that failure modes were mainly oblique shear failure, laminates bending failure, laminates tackless failure, while the end local pressure and overall bending failure occured less frequently. Compressive strength of bamboo was $1,5 \div 2$ times higher than that of wood. Elastic modulus of the two was similar, which makes them commonly used in foundations. After being compounded, compressive strength improved. After being combined with glued bamboo, it increased by $1,26 \div 32,05 \%$, and it increased by $0,80 \div 45,86 \%$ with reconsolidated bamboo. Bamboo-wood composites have high strength and good ductility, which can meet engineering requirements.

Keywords: bamboo-wood composites; compression performance; experimental study; failure mechanism

Istraživanje stlačivosti paralelne zrnate teksture slojevito lijepljenih kompozita bambus-drvo

Izvorni znanstveni članak

Istraživanje stlačivosti kompozita bambus-drvo predstavlja osnovu za izbor materijala za prednapregnute grede od bambusa i drveta i drugih komponenti čija se stlačivost uglavnom dijeli s kompozitima od lijepljenog bambusa i drveta. Odabrane su četiri vrste drveta i dvije vrste bambusa za 22 grupe (6 uzoraka u svakoj grupi) podijeljene u 4 serije za ispitivanje čimbenika koji utječu na vrstu materijala bambus/drvo, kao što su sastav, debljina ploče sloja (layer plate), i tipovi postavljanja lamela (lamina lay-ups type). Uspoređivani su i analizirani tlačna čvrstoća, modul elastičnosti, duktilnost i mehanizmi kvara. Rezultati su pokazali da je do loma uglavnom dolazilo zbog kosog smika (oblique shear failure), savijanja laminata, dok su se krajnji lokalni tlak i lom zbog uvijanja događali manje često. Tlačna čvrstoća bambusa bila je $1,5 \div 2$ puta veća nego tlačna čvrstoća drveta. Njihov je modul elastičnosti sličan zbog čega se uobičajeno koriste u temeljima. Nakon sastavljanja, tlačna se čvrstoća povećala. Nakon sastavljanja s lijepljenim bambusom, povećala se za $1,26 \div 32,05 \%$, a s rekonsolidiranim bambusom (nanovo učvršćenim) se povećala za $0,80 \div 45,86 \%$. Kompoziti bambus-drvo imaju visoku čvrstoću i dobru duktilnost, što može zadovoljiti tehničke potrebe.

Ključne riječi: bambus-drvo kompoziti; eksperimentalna studija; mehanizam kvara; stlačivost

\section{Introduction}

The bamboo-wood composite is the compound panel or square timber combined or glued by bamboo and wood in the same or different structural unit forms. It can diffuse or completely eliminate some defects of bamboo and wood as separate components, and improve the materials strength and solve the bamboo problems of having small grade diameters, low outturn percentage, and processing difficulty. Additionally, it can remedy the inadequacy of wooden low intensity, thus, the superior qualities of each of the two materials can be fully utilized $[1 \div 3]$. For traditional glued bamboo-wood beams, the materials compressive strength cannot be fully utilized in the state of bending, and the failure mode was brittleness tension failure. The glued bamboo-wooden beams deformation was larger, meaning the section size was controlled by deformation $[4 \div 6]$. Therefore, applying prestressing to a glued bamboo-wooden beam, the beam stress state was altered from pure bending to compression-bending. That is to say, for a compound component, the prestressed tendon was in tension, and the glued bamboo-wood was in compression; thus, the deformation was decreased and the material's strength was fully utilized. Therefore, the research of glued bamboo-wood composites compression performance tests provided a basis for the material selections of prestressed glued bamboo-wood beams and other components whose compression is mainly shared by glued bamboo-wood composites, and laid a foundation for the promotion of the excellent performance, economic benefits, applicability to higher-value products, which is of important theoretical value and engineering significance $[7,8]$.

At present, research globally on glued bamboo and glued wooden components is quite thorough; for example, in literature [9], the influence of bending performance on prestressing of glued wooden beams was studied, and in literature [10], the mechanical performance of glued bamboo-wooden structures bolt connections was studied. But for bamboo-wood composites, the current research is mainly focused on material performance, including the production technology, bending and shear performance of bamboo-wood composites $[11,12]$, The wet effect or the influence of various wet conditions, including fatigue and creep have also been studied [13, 14]. However, using the bamboo-wood composites as structural components and researching their mechanical performance has not been done so far. Thus, the research of mechanical performance tests on structures using bamboo-wood composites is of great significance.

In this paper, 132 laminated glued bamboo-wood composite prism specimens were tested in four batches parallel to the grain, and the influence factors on bamboo/wooden material type, such as composition pattern, layer plate thickness and lamina lay-ups type were considered comprehensively. Then the parallel to the grain compression performance of bamboo-wood composites was tested, which provided a basis for the material selections for prestressed glued bamboo-wooden beams and other components whose compression was 
mainly shared by glued bamboo-wooden composites $[15$, $16]$.

\section{Test general situation \\ 2.1 Test purpose}

Considering the influence factors of material type, composition pattern and layer plate thickness and lamina lay-ups type, the elasticity modulus, compressive strength, ductility, failure mechanism, deformation compatibility between bamboo and wood on bamboowood composites parallel to the grain were studied, and a basis of material selection for prestressed glued bamboowood beams and other components whose compression was mainly shared by glued bamboo-wood composites was provided.

\subsection{Specimens production}

On the choice of specimen materials, four kinds of domestic commonly used wood (SPF, poplar, eucalyptus and northeast larch) were selected. Additionally, glue and reconsolidated bamboos processed by advanced methods were selected. To decrease the influence of end local pressure on measurement results, the size of the glued bamboo-wood compressive specimens was determined as $100 \times 100 \times 300 \mathrm{~mm}$ [17]. Meanwhile, the laminates length direction was confirmed to be parallel to the grain. The glued bamboo-wood specimens used in this test were all processed by professional manufacturers, and the section form is shown in Fig. 1.
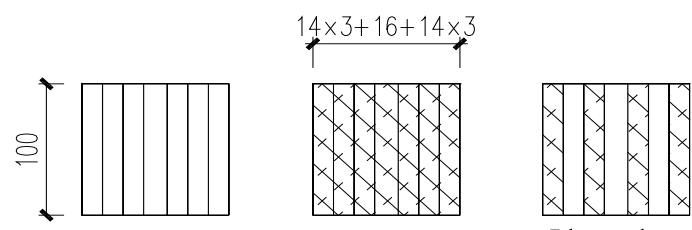

7 layer plates

a bamboo/wooden material type $\quad b$ bamboo-wood composites
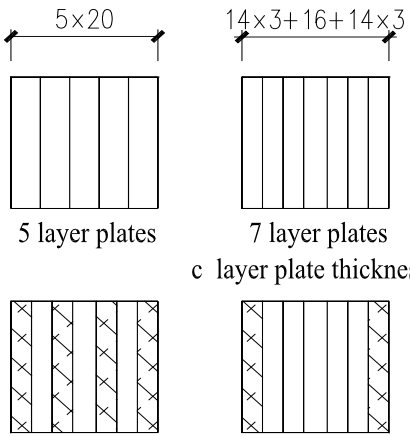

7 layer plates c layer plate thickness
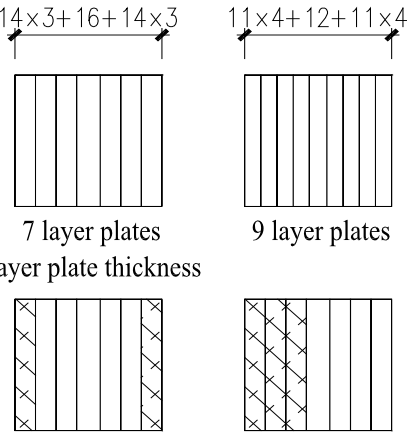

9 layer plates interval

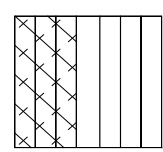

unilateral

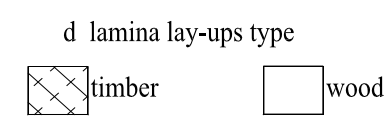

Figure 1 Specimens section form

In this test, 22 groups of specimens were processed in four batches, and due to the high degree of distinctiveness of the wood, six specimens were processed in each group to increase the test precision. In the first batch, the specimens were composed only of bamboo or wood, and the material with better compression performance was selected, which is shown in Fig. 1a. In

the second batch, the specimens were a combination of bamboo and wood, and the feasibility of a bamboo-wood composite and the deformation coordination degree of the two materials were discussed. The suitable bamboowooden composites were selected prior to that, which is shown in Fig. 1b. In the third batch, the composition material was the same, but the layer plate thickness was different, and the influence of the layer plate thickness on bamboo-wood composite compression performance was studied, results of which are shown in Fig. 1c. In the fourth batch, the composition material was the same, but the lamina lay-ups type was different, and the influence of lamina lay-ups type on bamboo-wood composite compression performance was studied, results of which are shown in Fig. 1d. The basic information on the specimens is shown in Tab. 1, in which the specimens of $2 \div 13$ and $2 \div 14$ groups were used in comparative analysis of the third and fourth batch tests, simultaneously.

Table 1 Basic information on the compression specimens

\begin{tabular}{|c|c|c|c|c|}
\hline Batch & $\begin{array}{l}\text { Specimen } \\
\text { group }\end{array}$ & Material & $\begin{array}{c}\text { Layer } \\
\text { number }\end{array}$ & $\begin{array}{c}\text { Lay-up } \\
\text { type }\end{array}$ \\
\hline \multirow{6}{*}{1} & $1-1$ & $\mathrm{~S}$ & 7 & - \\
\hline & $1-2$ & $\mathrm{E}$ & 7 & - \\
\hline & $1-3$ & $\mathrm{P}$ & 7 & - \\
\hline & $1-4$ & $\mathrm{~N}$ & 7 & - \\
\hline & $1-5$ & $\mathrm{G}$ & 7 & - \\
\hline & $1-6$ & $\mathrm{R}$ & 7 & - \\
\hline \multirow{8}{*}{2} & $2-7$ & $\mathrm{~S}+\mathrm{G}$ & 7 & I \\
\hline & $2-8$ & $\mathrm{~S}+\mathrm{R}$ & 7 & I \\
\hline & $2-9$ & $\mathrm{E}+\mathrm{G}$ & 7 & $\mathrm{I}$ \\
\hline & $2-10$ & $E+R$ & 7 & I \\
\hline & $2-11$ & $\mathrm{P}+\mathrm{G}$ & 7 & I \\
\hline & $2-12$ & $\mathrm{P}+\mathrm{R}$ & 7 & I \\
\hline & $2-13$ & $\mathrm{~N}+\mathrm{G}$ & 7 & I \\
\hline & $2-14$ & $\mathrm{~N}+\mathrm{R}$ & 7 & I \\
\hline \multirow{4}{*}{3} & $3-15$ & $\mathrm{~N}+\mathrm{G}$ & 5 & I \\
\hline & $3-16$ & $\mathrm{~N}+\mathrm{R}$ & 5 & I \\
\hline & $3-17$ & $\mathrm{~N}+\mathrm{G}$ & 9 & $\mathrm{I}$ \\
\hline & $3-18$ & $\mathrm{~N}+\mathrm{R}$ & 9 & I \\
\hline \multirow{4}{*}{4} & $4-19$ & $\mathrm{~N}+\mathrm{G}$ & 7 & $\mathrm{U}$ \\
\hline & $4-20$ & $\mathrm{~N}+\mathrm{R}$ & 7 & $\mathrm{U}$ \\
\hline & $4-21$ & $\mathrm{~N}+\mathrm{G}$ & 7 & B \\
\hline & $4-22$ & $\mathrm{~N}+\mathrm{R}$ & 7 & B \\
\hline
\end{tabular}

S - SPF; E - eucalyptus; P - poplar; $\mathrm{N}$ - northeast larch; $\mathrm{G}$ - glued bamboo; R - reconsolidated bamboo; I - interval; U - unilateral; B bilateral.

\subsection{Experiment device}

The experiment was conducted in a $2000 \mathrm{kN}$ computer controlled electro-hydraulic servo universal tester, shown in Fig. 2.

In order to measure the elasticity modulus of prism compression specimens, the self-development double-clip type extensometer with a standard distance of $100 \mathrm{~mm}$ and a range of $1 \mathrm{~mm}$ was used. The extensometer was installed in the middle of the specimens, and the upper and lower edges centre lines were confirmed to connect parallel to the specimen axis direction, which is shown in Fig. 3. To measure the specimens compressive strength and ultimate compression strain in the failure stage, the resistance displacement meter with a range of $20 \mathrm{~mm}, 100$ $\mathrm{t}$ tension-compression sensor and DH3816N static strain acquisition system were used. 


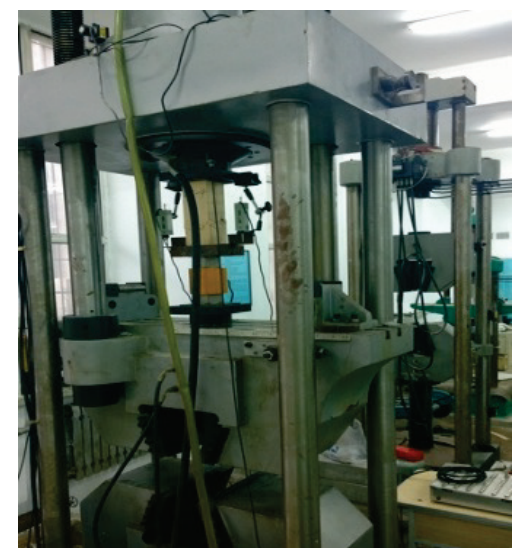

Figure 2 Computer controlled electro-hydraulic servo universal tester

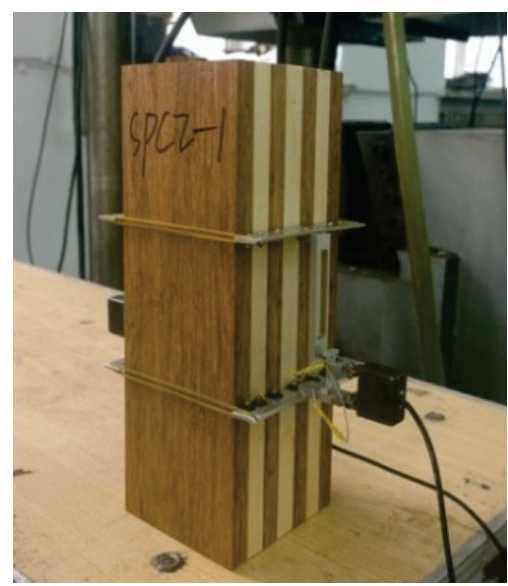

Figure 3 Double-clip type extensometer

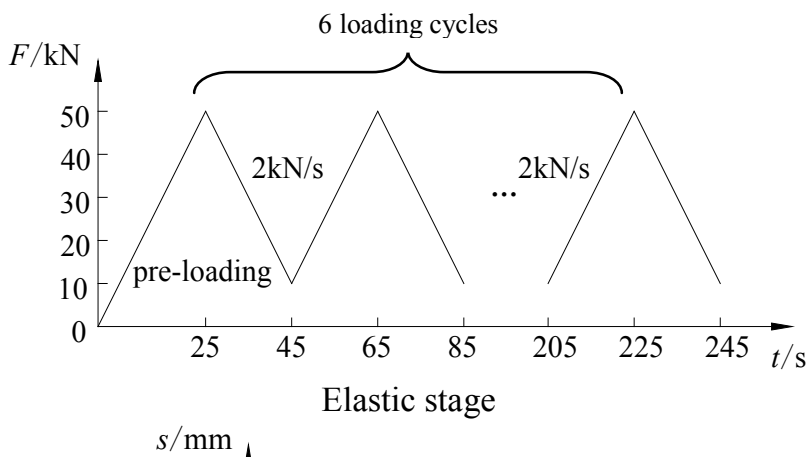

$s / \mathrm{mm}$

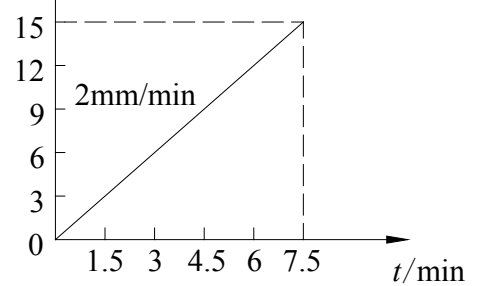

Failure stage

Figure 4 Loading system

\subsection{Loading system}

The loading process was controlled by force and displacement in the elastic stage. The loading speed was 2 $\mathrm{kN} / \mathrm{s}$ uniform, and the force was increased from $10 \mathrm{kN}$ to $50 \mathrm{kN}$ then unloaded to $10 \mathrm{kN}$, which is a loading cycle., Six loading cycles in all were completed. The failure stage was controlled by displacement, and the loading speed was $2 \mathrm{~mm} / \mathrm{min}$ uniform. The test was stopped when the target displacement of $15 \mathrm{~mm}$ was reached, and then the test data was derived. The loading mechanism of the two stages is shown in Fig. 4.

\section{Test results}

\subsection{Elastic deformation stage}

In the elastic deformation stage, the double-clip type extensometer was used to measure elasticity modulus, and the stress-strain relationship conformed to the Hooke Law. The elastic modulus of component could be calculated according to Eq. (1):

$$
E=\frac{\Delta \sigma}{\Delta \varepsilon}=\frac{\frac{N_{50}-N_{10}}{S}}{\frac{\Delta L_{50}-\Delta L_{10}}{L_{0}}} .
$$

where: $N_{10}, N_{50}$ is the value sensor under the loading force of $10 \mathrm{kN}$ or $50 \mathrm{kN}$ in an elastic cycle; $\Delta L_{10}, \Delta L_{50}$ is the deformation (mm) corresponding to $N_{10}, N_{50} ; \mathrm{S}$ is the compression area $\left(\mathrm{mm}^{2}\right) ; L_{0}$ is the standard distance of the extensometer.

\subsection{The analysis of compressive bearing capacity and section stiffness}

In the failure stage, based on "Method of testing in compressive strength parallel to grain of wood" (GB/T 1935-2009), the compressive strength could be calculated according to Eq. (2) [18]:

$\sigma_{W}=\frac{P_{\max }}{b \cdot t}$.

where $\sigma_{W}$ was the compression strength parallel to grain when the sample water rate is $W, P_{\max }$ is the failure load, $b$ is specimen width, $t$ is specimen thickness.

Table 2 Comparison of compression resistance capability of glued bamboo-wooden composites

\begin{tabular}{|c|c|c|c|c|c|}
\hline$B$ & $S G$ & $E / \mathrm{MPa}$ & $E C / \%$ & $S / \mathrm{MPa}$ & $S C / \%$ \\
\hline \multirow{6}{*}{1} & $1-1$ & 9317,44 & 4,13 & 25,12 & 4,22 \\
\hline & $1-2$ & 10569,63 & 17,78 & 34,79 & 0,73 \\
\hline & $1-3$ & 7901,39 & 0,87 & 26,99 & 1,49 \\
\hline & $1-4$ & 11994,36 & 2,35 & 32,50 & 0,83 \\
\hline & $1-5$ & 9507,15 & 1,55 & 45,76 & 0,35 \\
\hline & $1-6$ & 11359,75 & 3,03 & 55,73 & 0,97 \\
\hline \multirow{8}{*}{2} & $2-7$ & 8520,90 & 4,57 & 33,17 & 0,81 \\
\hline & $2-8$ & 11108,96 & 10,52 & 36,64 & 0,68 \\
\hline & $2-9$ & 9147,24 & 2,01 & 35,24 & 2,44 \\
\hline & $2-10$ & 12320,72 & 2,11 & 38,56 & 4,82 \\
\hline & $2-11$ & 8549,63 & 7,92 & 32,07 & 0,10 \\
\hline & $2-12$ & 9909,76 & 3,81 & 38,17 & 0,80 \\
\hline & $2-13$ & 9551,11 & 0,11 & 34,68 & 0,93 \\
\hline & $2-14$ & 12112,83 & 0,22 & 39,53 & 3,57 \\
\hline \multirow{4}{*}{3} & $3-15$ & 12959,38 & 8,20 & 41,92 & 0,46 \\
\hline & $3-17$ & 9720,53 & 0,18 & 38,13 & 0,18 \\
\hline & $3-16$ & 11754,56 & 0,17 & 43,62 & 0,55 \\
\hline & $3-18$ & 12677,93 & 15,43 & 46,63 & 0,39 \\
\hline \multirow{4}{*}{4} & $4-19$ & 9415,95 & 6,32 & 33,51 & 2,87 \\
\hline & $4-21$ & 9414,21 & 0,13 & 32,93 & 0,17 \\
\hline & $4-20$ & 11686,98 & 15,25 & 39,27 & 3,56 \\
\hline & $4-22$ & 10173,98 & 3,23 & 34,69 & 0,33 \\
\hline
\end{tabular}


Where $B$ - Batch; $S$ - Specimens group; $E$ - elasticity modulus; $E C$ - elasticity modulus variable coefficient; $S$ - strength; $S C$ - strength variable coefficient.

To improve the precision of the test results [19], the nearest 4 specimens in a group were selected, then the average taken. The comparison of compression resistance capability is shown in Tab. 2.

\section{Result analysis}

\subsection{Failure mode and mechanism analysis}

Five typical failure modes can be obtained after induction analysis of the specimens damaged, which is shown in Fig. 5. The first mode is end local pressure failure; at the end of the specimen within $30 \mathrm{~mm}$, the bamboo and woods fiber were instable due to compression, and a transverse fold formed in the specimen surface. The second mode is oblique shear failure; because of defects and initial eccentricity, an approximately $45^{\circ}$ oblique crack was formed in the middle of the specimen. The third mode is laminates bending failure, which appeared usually in interval layouts in the bamboo-wood composites. The elastic deformation susceptibility of wood was lower than that of bamboo, so the compressive buckling occurred on woods of middle layers, then part of the woods were out of work, followed by bamboo buckling and damage to the specimen. The forth mode is laminates tackless failure, occurring mostly on bamboo-wooden composite specimens, which was the combination of glued bamboo and wood. This was because there was a difference in deformation between bamboo and wood, and the bonding between the glued bamboo surface and wood was not ideal, leading to scuffing surface cracking. The fifth mode is the overall bending failure, which occurred mostly on the glued bamboo specimen due to better ductility and toughness. Lateral bending occurred after compression, but significant cracks or folds did not appear until the end of loading [20]. By statistical analysis, the percentage of the five typical failure modes was $27,9 \%, 9,3 \%, 18,6 \%$, $30,2 \%$, 13,9 \%, being mainly oblique shear failure, laminates bending failure, laminates tackless failure.

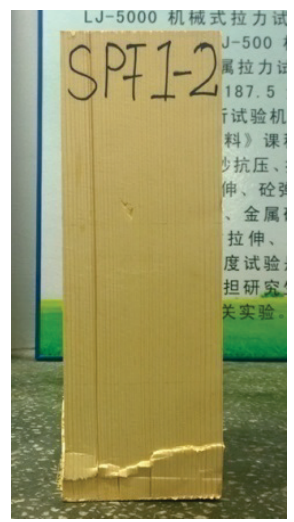

(1) end local pressure failure

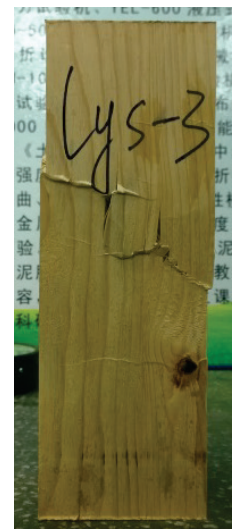

(2) oblique shear failure

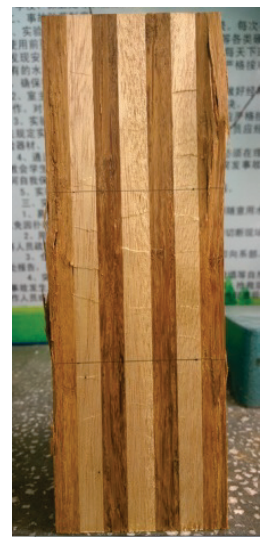

(3) laminates bending failure

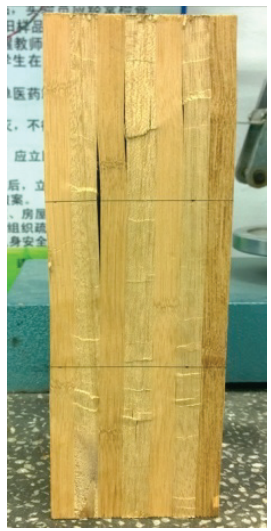

(4) laminates tackless failure

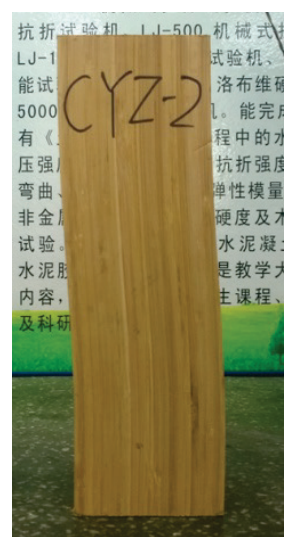

(5) overall bending failure

Figure 5 Typical failure modes of the specimens

\subsection{The analysis of compression performance}

(1) Comparison and analysis of specimens with a single material

The parallel to the grain compressive strength and elasticity modulus of prism specimens composed of single bamboo or wood is shown in Fig. 6. Of the four kinds of wood selected, eucalyptus had the highest parallel to the grain compressive strength. The northeast larch had the greatest elasticity modulus and a higher compressive strength, as well as the best comprehensive compression performance. Of the two bamboo materials, the compression performance of the reconsolidated bamboo was better than the glued bamboo. Overall, the compressive strength of the bamboo was 1,5 2 times greater than wood. The compressive elastic modulus of the two was similar, which means they have a common work foundation.

(2) Comparison and analysis of bamboo-wood composite specimens

The parallel to the grain compressive strength and elasticity modulus of the bamboo-wood composite specimens are shown in Fig. 7. It can be seen that after compounding, the compressive strength improved more than the glued wood component, with an increase of 1,26 $\div 32,05 \%$ after being combined with glued bamboo, and the strength increased by $0,80 \div 45,86 \%$ when combined with reconsolidated bamboo. Due to the high strength of the reconsolidated bamboo and the security bonding between the reconsolidated bamboo and wood, its compression performance was better.

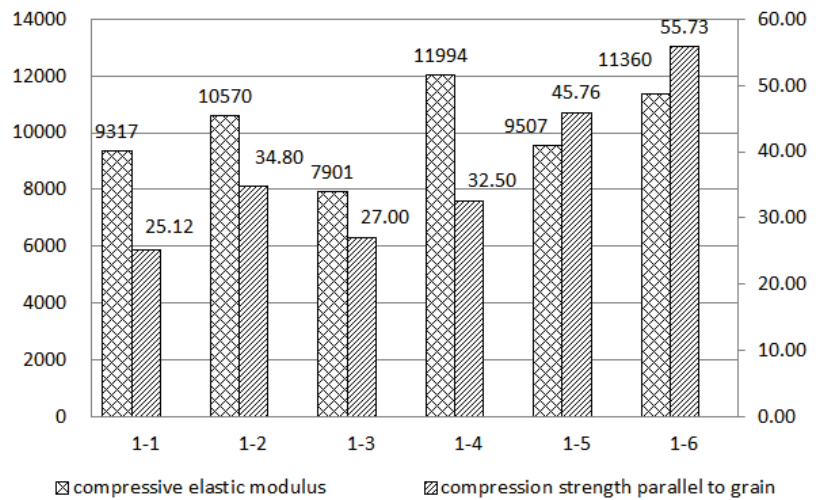

Figure 6 Compression performance index comparison diagram of prism specimens with a single material 
Table 3 The range of increase in compression strength of bamboo-wood composites

\begin{tabular}{|c|c|r|}
\hline Group & Material & Increased range $/ \%$ \\
\hline $2-7$ & $\mathrm{~S}+\mathrm{G}$ & 32,05 \\
\hline $2-8$ & $\mathrm{~S}+\mathrm{R}$ & 45,86 \\
\hline $2-9$ & $\mathrm{E}+\mathrm{G}$ & 1,26 \\
\hline $2-10$ & $\mathrm{E}+\mathrm{R}$ & 10,80 \\
\hline $2-11$ & $\mathrm{P}+\mathrm{G}$ & 18,78 \\
\hline $2-12$ & $\mathrm{P}+\mathrm{R}$ & 41,37 \\
\hline $2-13$ & $\mathrm{~N}+\mathrm{G}$ & 6,74 \\
\hline $2-14$ & $\mathrm{~N}+\mathrm{R}$ & 21,63 \\
\hline
\end{tabular}

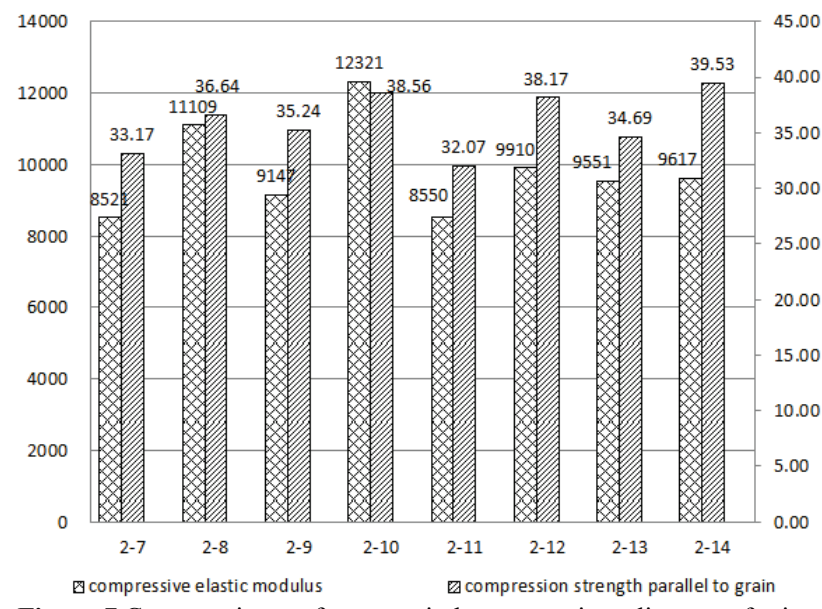

Figure 7 Compression performance index comparison diagram of prism specimens with different materials

(3) Comparison and analysis of specimens with different layer plate thickness

In the third batch, the layer plate thickness was 20 $\mathrm{mm}, 14 \mathrm{~mm}$, and $11 \mathrm{~mm}$. The parallel to the grain compressive strength and elasticity modulus of specimens with different layer plate thickness are shown in Fig. 8, showing that when the layer plate thickness of the two specimens was $14 \mathrm{~mm}$, the compressive strength and elasticity modulus were minimal, but with another thickness, the compressive strength and elasticity modulus were greater. This is because when the plate thickness was $20 \mathrm{~mm}$, high strength bamboo comprised a high percentage of the whole specimen, so the compression performance was higher. However, when the plate thickness was $11 \mathrm{~mm}$, the defects were more dispersed, and the compression performance was better, as well. Thus, for the bamboo-wood composite specimens, smaller thickness yielded better compression performance, and higher bamboo content yielded a better compression performance.

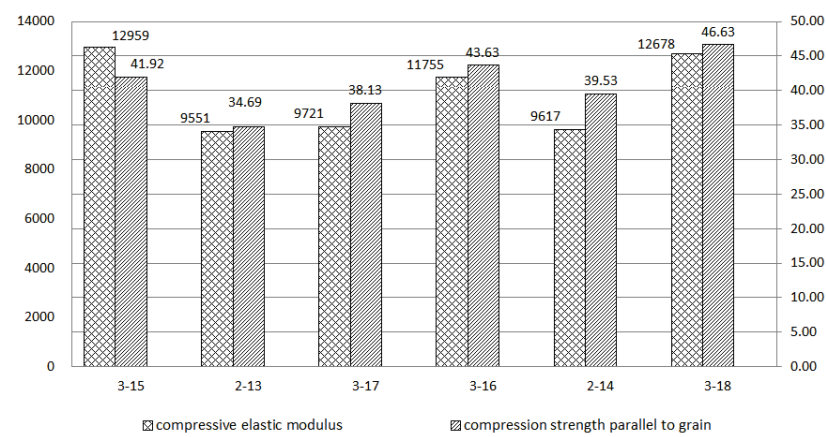

Figure 8 Compression performance index comparison diagram of prism specimens with different layer plate thicknesses
(4) Comparison and analysis of specimens with different lamina lay-ups type

The parallel to the grain compressive strength and elasticity modulus of specimens with different lamina layups type are shown in Fig. 9. Among the three lamina layups types, the compression performance was best with interval layout. When the bamboo was arranged at one side, the eccentric compression formed because the wood was initially damaged in the loading process, and the compression ability of the bamboo was not sufficiently utilized. However, because the bamboo content was higher than the specimen of interval layout, this ultimately lead to the close compression performance of the two situations.

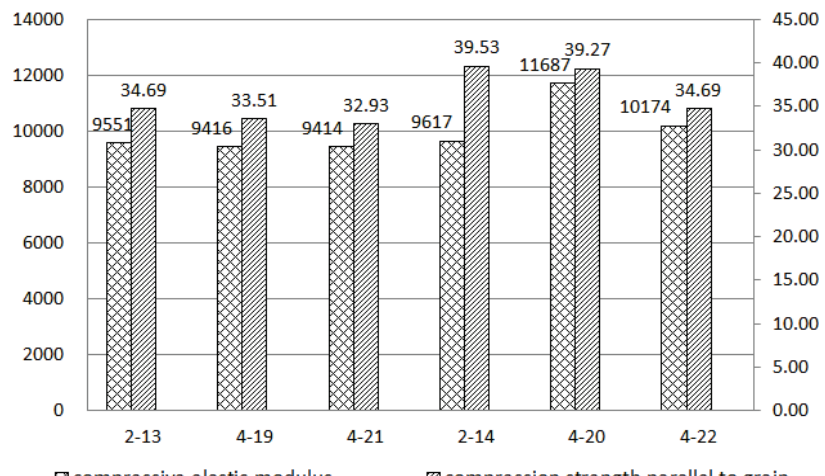

Figure 9 Compression performance index comparison diagram of prism specimens with different lamina lay-ups type

\subsection{Ductility analysis}

The ductility is an important performance aspect of material that affects the deformability and seismic capacity directly. In the 22 groups of specimens, specimens with a layer plate thickness of $14 \mathrm{~mm}$, interval layout, northeast larch wood, glued bamboo and reconsolidated bamboo were selected. Two comparison groups were formed according to the type of bamboo, with glued wood, glued bamboo and bamboo-wooden composites contained in each group. The loadingdisplacement curve of the two groups is shown in Figs. 10 and 11 .

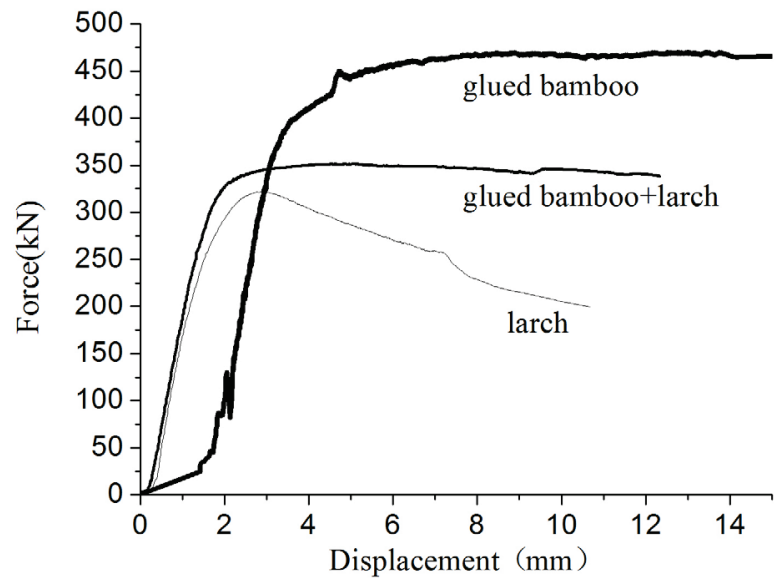

Figure 10 The loading-displacement curve comparison of the glued bamboo group

Fig. 10 shows that the bearing capacity gradually decreased when the glued wood reached the peak load, 
but when the load of glued bamboo reached $4 \mathrm{~mm}$, the load slowly increased and the displacement increased. Good ductility appeared, and when the load of the bamboo-wood composites reached the peak it remained unchanged.

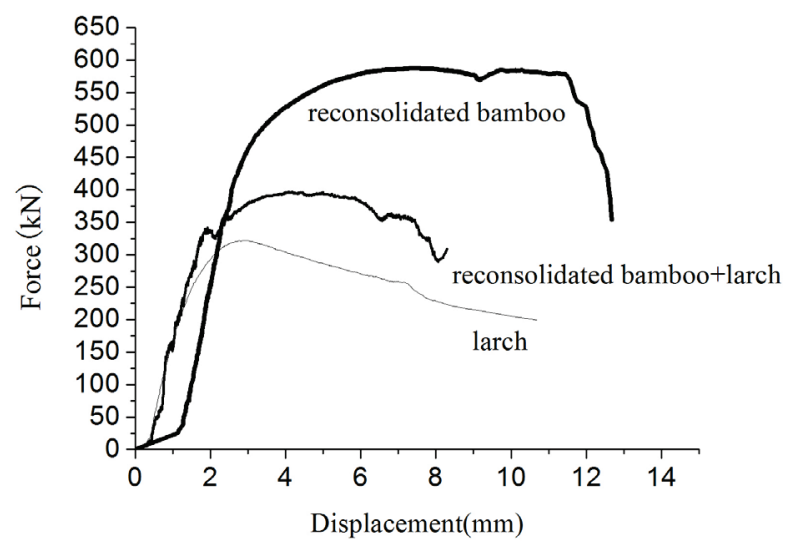

Figure 11 Loading-displacement curve comparison of the reconsolidated bamboo group

Fig. 11 shows that the displacement increased and the load remained unchanged when the reconsolidated bamboo reached the peak load. When the displacement exceeded $11 \mathrm{~mm}$, the bearing capacity rapidly decreased due to the bamboo fibre damage. The bamboo-wood composites were the combination of reconsolidated bamboo and northeast larch, which had slightly higher ductility than glued wood. The decrease in bearing capacity occurred when the displacement was more than 6 $\mathrm{mm}$. The laminates bending failure occurred because of bending in turn after a combination of the two.

Above all, the ductility of bamboo was much better than wood, and the ductility of glued bamboo and reconsolidated bamboo were best. The ductility of bamboo-wood composites was slightly better than glued wood, which can meet the demands of engineering applications.

\section{Conclusion}

(1) When the prism specimens were under compression, the percentage of the five typical failure modes of end local pressure failure, oblique shear failure, laminates bending failure, laminates tackless failure and overall bending failure were $27,9 \%, 9,3 \%, 18,6 \%, 30,2 \%$, $13,9 \%$, that is to say, in five typical failure modes, the end local pressure failure, laminates bending failure and laminates tackless failure occurred more frequently.

(2) The compressive strength of the bamboo was $1,5 \div 2$ times higher than that of wood, and the compressive elastic modulus of the two was similar, showing the possibility of them working well together.

(3) After compounding, the compressive strength improved greater than the glued wood component, increasing by $1,26 \div 32,05 \%$ after being combined with glued bamboo and by $0,80 \div 45,86 \%$ after being combined with reconsolidated bamboo. Overall, compression performance of specimens combining reconsolidated bamboo with wood was better.

(4) In the bamboo-wood composite, the glued bamboo was superior to reconsolidated bamboo in the improvement of ductility of specimens. Overall, the ductility was slightly better than glued wood after being compounded.

\section{Acknowledgement}

In the process, this project was supported by the National Natural Science Foundation of China (51208083) and the Natural Science Foundation of Heilongjiang Province (E201402).

\section{Reference}

[1] Hai-tao, Li; Qi-sheng, Zhang; Dong-sheng, Huang; Andrew John, Deeks. Compressive performance of laminated bamboo. // Composites Parts B: Engineering. 54, 11(2013), pp. 319-328.

[2] $\mathrm{Li} \mathrm{Li}$, Qing. The current situation of glued-laminated limber structure housing. // China building materials science and technology. 17, 1(2008), pp. 63-66.

[3] Li Li, Qing. The research of glued timber structure miniature building structure design principle. Nan Jing : Nanjing Forestry University, 2005.

[4] Folz, B. Seismic analysis of wood frame structures. I: Mode 1 formulation, and II: Model Implementation and verification. // Journal of Structural Engineering. 130, 9(2004), pp. 1353-1370. DOI: 10.1061/(ASCE)07339445(2004)130:9(1353)

[5] Liu Wei, Qing; Yang Hui, Feng. The bending performance of timber beam. // Journal of building structures. 29, 1(2008), pp. 90-95.

[6] Parker, H.; Ambrose, J. Simplified design of wood structures.//China Water Power Press \& Intellectual Property Press.2008:6-9.

[7] De Luca, V.; Marano, C. Prestressed glulam timbers reinforced with steel bars. // Construction and Building Materials. $\quad 30, \quad 5(2012)$, pp. 206-217. DOI: 10.1016/j.conbuildmat.2011.11.016

[8] Zuo, H. L.; He, D. P.; Wang, D. Y.; Wang, Y. B Performances of glued-laminated timber in the compressive zone of prestressed glulam beams. // Journal of Northeast Forestry University. 42, (2014), pp. 90-94.

[9] Lin, Cheng; Yang Hui, Feng; Liu Wei, Qing; Lu Wei, Dong; Ling Zhi, Bin; Hao Jian, Dong. Experimental Study on flexural behavior of pre-stressed scuffing timber beam. // Structure Engineer. 30, 1(2014), pp. 160-164.

[10] Feng, Li; Xiao, Yan; Shan, Bo; Chen, Jie; Shen, Ya Li; Experimental study on bearing capacity of beam column joints glued bamboo structure connecting bolt. // Journal of building structures. 35, 4(2014), pp. 230-235.

[11] Liu, Zhi Kun; Hu, Na Na. The preliminary study of Bamboo and wood composite sekishige joist lumber production technology. // Forest Product Industry. 36, 1(2009), pp. 21-24

[12] Zhu, Yi Xin; Cheng, Li Mei; Guan, Ming Jie. The study on horizontal shear strength of Bamboo-wood composite board. // Journal of Northwest Forestry University. 21, 6(2006), pp. 180-182.

[13] Upadhyay, P. C.; Lyons, J. S. Effect of hydrothermal environment on the bending of PMC laminates under large deflection. // J Reinf Plast Compos. 19, 6(2000), pp. 465 491. DOI: 10.1106/5TP7-CX5C-88RK-BJ4C

[14] Woodie, J. M. D. Creep in chipboard (III): Initial assessment of the influence of moisture content and level of stressing on rate of creep and time to failure. // Wood Sci Tech. 15, 6(1981), pp. 125-144. 
[15] Japan Plywood Inspection Corporation. Japanese Agricultural Standard SE-90: Japanese Agricultural Standard for Structural Glued Laminated Timber. / Tokyo, Japan: Japan Plywood Inspection Corporation, 2000.

[16] Dadras, P.; McDowell, J. S. Analytical and experimental evaluation of double-notch shear strength of orthotropic materials. // Experimental Mechanics. 61, (1990), pp. 184189. DOI: $10.1007 / \mathrm{BF} 02410246$

[17] Guo, Nan; Liu, Xiu Xia; He, Tie. The Research on Methods of Glue-lumber Compressive Properties Test. // Information Technology Journal. 22, 12(2013), pp. 6646-6650.

[18] Wood Structures Design Manual. Editorial Board. Wood structures design manual. / Third Edition. Bei Jing: China Architecture \& Building Press, 2005.

[19] Wood structure test method standard (GB /T 50329-2012). / Bei Jing : China Architecture \& Building Press.

[20] Frühwald Hansson, E. Analysis of structural failures in timber structures: Typical causes for failure and failure modes. // Engineering Structures. 33, 11(2011), pp. 29782982. DOI: $10.1016 /$ j.engstruct.2011.02.045

\section{Authors' addresses}

Guo Nan, doctor, associate professor Northeast Forestry University, 26 Hexing Rd, Xiangfang, Harbin, Heilongjiang Province 150040, China E-mail: snowguonan@163.com

\section{Chen Huihui, student}

Northeast Forestry University, 26 Hexing Rd, Xiangfang, Harbin, Heilongjiang Province 150040, China E-mail: sunnychh4549@163.com

\section{Zhang Pingyang, student} Northeast Forestry University, 26 Hexing Rd, Xiangfang, Harbin, Heilongjiang Province 150040, China E-mail: 839561810@163.com

Zuo Hongliang, doctor, professor Northeast Forestry University, 26 Hexing Rd, Xiangfang, Harbin, Heilongjiang Province 150040, China E-mail: zh19163@163.com 